\title{
THIOPHENE CRACKING USING MAGNESIUM MODIFIED BETA ZEOLITE
}

\section{CRAQUEAMENTO DO TIOFENO UTILIZANDO ZEÓLITA BETA MODIFICADA COM MAGNÉSIO}

R. C. SANTOS ${ }^{1,4^{*}}$, D. F. ALMEIDA ${ }^{2}$, F. S. C. FONSECA ${ }^{1}$, D. D. DA SILVA ${ }^{1}$, A. A. DE OLIVEIRA ${ }^{1}$, D. A. PONTES $S^{2,3}$ and L. A. M. PONTES ${ }^{2,4}$

${ }^{1}$ Universidade Salvador (UNIFACS), Department of Engineering, Salvador, Bahia, Brazil

${ }^{2}$ Universidade Federal da Bahia (UFBA), Institute of Chemistry Engineering, Salvador, Bahia, Brazil

${ }^{3}$ Universidade Federal de São Carlos (UFSCar), Department of Chemical Engineering, São Carlos, São Paulo, Brazil ${ }^{4}$ Instituto Brasileiro de Tecnologia e Regulação (IBTR), Salvador, Bahia, Brazil

${ }^{*}$ Ronaldo Costa Santos. Salvador University, Department of Chemical Engineering, Salvador, Bahia, Brazil, Phone: +55 7198666-6425

e-mail address: Ronaldo.ead@gmail.com (R.C. Santos).

\section{A R T I C L E I N F O}

Article history:

Received 2018-09-19

Accepted 2018-10-15

Available online 2018-10-31

\section{palavras-chave}

Craqueamento catalítico

Zeólitas Beta

Tiofeno

\section{keywords}

Catalytic cracking

Beta zeolites

Thiophene
A B S T R A C T

The development of additives for FCC catalysts aiming at a greater sulfur removal in the gasoline fraction has been a priority with tougher environmental legislation demands. In this context, this study has evaluated the effect of magnesium modified beta zeolite on n-hexane cracking, and the catalytic conversion of thiophene added as contaminant. Catalytic tests' results, performed at low conversion at $400{ }^{\circ} \mathrm{C}$ with a WHSV of $0.83 \mathrm{~s}^{-1}$ indicate that magnesium addition increased n-hexane cracking from 37.7 to $53.6 \%$ in mols, but favored the formation of alkylated sulfur compounds over $\mathrm{H}_{2} \mathrm{~S}$ production.

\section{R E S U M O / R E S U M E N}

O desenvolvimento de aditivos para catalisadores de FCC visando a uma maior remoção do enxofre na faixa da gasolina tem sido prioridade com a maior exigência da legislação ambiental. Nesse contexto, este trabalho avaliou o efeito da zeólita beta modificada com magnésio sobre o craqueamento do n-hexano e sobre a conversão catalítica de tiofeno, adicionado como contaminante. Os resultados dos testes catalíticos, realizados em baixa conversão a $400{ }^{\circ} \mathrm{C}$ com WHSV de 0,83 $\mathrm{s}^{-1}$, indicaram que a adição de magnésio aumentou o craqueamento do n-hexano de 37,7 para 53,6\% em mol, mas favoreceu a formação de compostos de enxofre alquilados em detrimento da produção de $\mathrm{H}_{2} \mathrm{~S}$. 


\section{INTRODUCTION}

Fluidized catalytic cracking (FCC) is one of the most important petroleum refining processes for the production of gasoline (KARAKHANOV et al., 2016). The process'main inlet is gasoil primarily from vacuum distillation, and atmospheric distillation, which possesses a significant amount of sulfur. In the FCC process, these sulfur compounds are cracked, leading to sulfurized compounds in the gasoline fraction. As a result, the gasoline from FCC units concentrates circa $90 \%$ of such contaminant in the gasoline pool, demanding investments in subsequent hydrotreatment processes (RIO; BASTOS; SEDRAN, 2013). The removal of these sulfurized compounds happens in the hydrodesulfurization units (HDS), which promote the C-S bond breaking, and the formation of $\mathrm{H}_{2} \mathrm{~S}$ (GUPTA, IBRAHIM e SHOAIBI, 2016). In HDS, the challenge lies in catalyzing hydrogen reactions selective to thiophenes and benzothiophenes, without, nonetheless, hydrogenating unsaturated hydrocarbons which lead to a higher gasoline octane count (LEFLAIVE et al., 2002). On the other hand, HDS increases fuel production costs because it consists of an additional unit with higher energy cost and large amounts of hydrogen.

The cracking reaction of organosulfur compounds are concentrate in the gasoline fraction in the FCC unit itself, through the use of additives to the catalyst, presents itself as an interesting solution to be studied. Several authors indicate that these sulfur compounds rearrange in a similar way to pure FCC hydrocarbons (CORMA; SAUVANAUD, 2013).

Since the 1960's, most FCC catalysts have contained zeolites as an active component. The $\mathrm{Y}$ type zeolite (faujasite) is the most used for possessing greater stability under process operational conditions (ZAFARI; KHARAT, 2013). Besides advances in the development of FCC catalysts, additives also play an important role in the advancement of this technology. Some additives are employed to the FCC catalyst in order to increase gasoline octane count, decrease coke formation or reduce sulfur content in gasoline. Specifically, as for gasoline sulfur content reduction, several metals supported on different oxides and aluminosilicate materials have been studied (KARAKHANOV et al., 2016; LEE; VALLA, 2017).

Zeolitic additives to the FCC catalyst containing Bronsted and Lewis acidic sites of different strengths promote adsorption and cracking of sulfurized compounds in the gasoline fraction. The Beta zeolite has been studied as an additive due to its high adsorptive selectivity and activity for catalytic cracking of thiophenic compounds (DEHGHAN e ANBIA, 2017). The incorporation of metallic ions as a catalytic promotor alters the acidity of catalytic sites on the zeolite and increases its adsorptive capacity, promoting desulfurization. (PENZIEN et al., 2004).

Aiming at advancing in the investigation of new additives to the FCC catalyst, this paper evaluates the effect of the magnesium modified beta zeolite on n-hexane cracking, and its influence on thiophene transformation reactions added as a contaminant in the $n$-hexane stream.
A commercial ammoniacal Beta zeolite (BEA CP814N) from Zeolyst International with SAR 18 was used. The zeolite in its protonic form - H-Beta - was obtained after calcination of the ammoniacal zeolite for $4 \mathrm{~h}$ in a muffle oven under air flow, at $500{ }^{\circ} \mathrm{C}$. The magnesium was incorporated into the Beta zeolite through the cationic exchange method. Hexahydrate magnesium nitrate $\left(\mathrm{Mg}\left(\mathrm{NO}_{3}\right)_{2} \cdot 6 \mathrm{H}_{2} \mathrm{O}\right)$, SigmaAldrich/Vetec (P.A. 99\%) was used as precursor. For the cationic exchange process, the Beta zeolite in its protonic form was kept under constant stirring with a $0.1 \mathrm{M}$ magnesium solution at room temperature for $48 \mathrm{~h}$. After filtration and washing with deionized water, the catalyst precursor was dried, calcinated, and sieved.

The chemical composition of elements present in the catalysts was determined by dispersive energy X-ray fluorescence (EDXRF) in a Bruker model S2 Ranger equipment, under helium flow, with an exposition time of $200 \mathrm{~s}$ and operation conditions of the radiation source specified for each chemical element indicated ( $\mathrm{Si}, \mathrm{Al}$ e $\mathrm{Mg}$ ).

The surface area and pore size distribution were measured using the Quantachrome model Nova-2000 equipment through $\mathrm{N}_{2}$ adsorption at $-196{ }^{\circ} \mathrm{C}$ by the BET method (Brunauer-Emmett-Teller) and the BJH methodology (Barrett-Joyner-Halenda) for adsorption isotherms, respectively. Circa $0.1 \mathrm{~g}$ of sample was pretreated at $300{ }^{\circ} \mathrm{C}$ under vacuum for 1 hour before each analysis.

The reactional study was conducted using a reaction system with a tubular reactor, in gaseous phase. Temperature control was performed by a cylindrical resistance furnace involving the central part of the reactor. Reactants were fed via a high performance isocratic infinite dosing pump model 1260 Infinity Series, Agilent Technologies, injecting the reactional mixture into an evaporator vessel heated under $\mathrm{N}_{2}$ atmosphere and controlled pressure. The reactants were kept under helium pressure in order to avoid contamination of the reaction medium with external environment gases. Pore size and flow parameters were defined as to operate with a space velocity (WHSV) of $0.83 \mathrm{~s}^{-1} .5 \mathrm{mg}$ of catalyst were used in each reaction, at a temperature of $400{ }^{\circ} \mathrm{C}$. The catalysts were pretreated under nitrogen atmosphere at $500{ }^{\circ} \mathrm{C}$, for $2 \mathrm{~h}$, before each reactor test. The reaction mixture is composed of 100 ppm thiophene (99\% A.C.S. reactant, Sigma-Aldrich) in n-hexane $(\geq 99 \%$ A.C.S. reactant, Sigma-Aldrich). Thiophene was used as a model molecule representing organosulfates and n-hexane as a paraffinic component of gasoline.

The online analysis system is composed of a chromatographer model 7890B, Agilent Technologies with automatic sampling, flame ionization detector (FID) and sulfur detection by chemiluminescence with a double plasma burner (SCD-DP). For determining hydrocarbons, a Chlorinated Alumina capillary column $50 \mathrm{~m}$ x $0.32 \mathrm{~mm}$ x 5 $\mu \mathrm{m}$, with a split ratio of 100:1. After product quantification, conversion and catalytic selectivity of n-hexane and thiophene were calculated using equations 1,2 , and 3 . The terms $\mathrm{mol}^{0}$ and mol refer to the number of molecules in mols in the reactor inlet and outlet, respectively. 


$$
\begin{aligned}
& \text { Conversion }_{\text {hexane }}(\%)=\frac{\text { mol }_{\text {hexane }}^{o}-\text { mol }_{\text {hexane }}}{\text { mol }_{\text {hexane }}^{o}} .100 \\
& \text { Conversion }_{\text {thiophene }}(\%)=\frac{\text { mol }_{\text {thiophene }}^{o}-\text { mol }_{\text {thiophene }}}{\text { mol }_{\text {thiophene }}^{o}} .100 \\
& \text { Seletivity }_{X}(\%)=\frac{\text { mol }_{\text {product } X}}{\sum \text { mol }_{\text {products }}} \cdot 100
\end{aligned}
$$

Hydrogen transfer index (HT) is an important parameter for measuring cracking capacity and is measurable from the alkane/alkene ratio of cracked products (CORMA et al., 1995). For this study, the parameter was measured using Equation 4.

$$
H T=\frac{\sum \text { mol }_{\text {paraffins }}}{\sum \text { mol }_{\text {olefins }}+\sum \text { mol }_{\text {dienes }}}
$$

\section{RESULTS AND DISCUSSION}

\subsection{Catalyst chemical and textural analyses}

Textural and chemical analyses of catalysts were performed by nitrogen adsorption techniques (BET) and FRX. The obtained results are shown in Table 1. (The results obtained are shown in Table 1).

Table 1 -Catalyst analyses

\begin{tabular}{ccc} 
Parameter & H-BEA & Mg-BEA \\
\% Mg (mass) & 0.0 & 0.4 \\
$\mathrm{Si} / \mathrm{Al}$ & 20.7 & 22.3 \\
$\mathrm{Mg} / \mathrm{Al}$ & 0.00 & 0.16 \\
Surface area $(\mathrm{BET})\left(\mathrm{m}^{2} / \mathrm{g}\right)$ & 560 & 525 \\
Pore volume $(\mathrm{BJH})\left(\mathrm{cm}^{3} / \mathrm{g}\right)$ & 0.42 & 0.49 \\
\hline
\end{tabular}

No significant variation was observed on pore surface area or volume after magnesium incorporation into the zeolite. It can be inferred that magnesium incorporation did not provoke textural changes on the Beta zeolite. From EDXRF results, the molar ratios $\mathrm{SiO}_{2} / \mathrm{Al}_{2} \mathrm{O}_{3}$ (SAR) and $\mathrm{Mg} / \mathrm{Al}$ in the catalysts were determined. The metallic contents found were similar to those calculated, confirming the experimental procedure success.

\subsection{Catalytic conversion of hexane}

$\mathrm{N}$-hexane and thiophene conversion catalytic tests were performed simultaneously, under low conversion regime $(<10 \%)$. In the catalytic conversion of $n$-hexane, cracking, isomerization, dehydrogenation, cyclization, and oligomeric products formation were observed (Table 2).

Table 2 -Selectivity of products in the conversion of $n$ hexane in mole base

\section{Selectivity}

HT

\section{H-BEA Mg-BEA}

\begin{tabular}{ccc} 
Cracking & 37.7 & 56.3 \\
Isomerization & 58.3 & 38.3 \\
Dehydrogenation & 0.5 & 1.0 \\
Cyclization & 2.7 & 3.8 \\
Olygomers & 0.8 & 0.6 \\
\hline
\end{tabular}

The catalytic activity of the Beta zeolite can be adjusted by modifying its texture and electronic properties by metal incorporation. These modifications provoke a variation in its acidity and adsorptive capacity of sulfurized compounds.

We observed that magnesium incorporation into the Beta zeolite promoted an increase in selectivity to cracking products and a decrease to isomerization products. Noda et al. (2008), while studying Y zeolites modified with alkalineearth cations by cationic exchange, perceived that octane cracking activity increased with the increased degree of ionic exchange, so that the authors confirmed, theoretically by functional density calculation, increase in acidic strength of Bronsted sites $\mathrm{OH}$ due to the introduction of metallic cations. In their studies on the effects of the incorporation of alkalineearth cations into ZSM-5, Lersch and Banderman (1991) affirmed that, with the addition of metals, there was an increase in the number of strong acidic sites on the catalysts.

In the conversion of $n$-hexane, the formation of the carbocation is a common initial step both for isomerization reactions and cracking reactions. These occur in Bronsted acidic sites, and there is a relationship between catalytic activity and the strength of these sites (CORMA \& SAUVANAUD, 2013). With this in mind, we can infer that the incorporation of magnesium into the Beta zeolite by cationic exchange promoted an increase in the number of stronger Bronsted acidic sites, promoting the formation of cracking products over the formation of isoparaffins.

\subsection{Thiophene catalytic conversion}

The products observed from thiophene cracking in the n-hexane stream containing $100 \mathrm{ppm}$ originated from hydrogenation reactions $\left(\mathrm{H}_{2} \mathrm{~S}\right.$ and hydrothiophenic compounds), cracking reactions (mercaptans), alkylation reactions (methyl, ethyl, and propyl thiophenic), and condensation (benzene, dibenzothiophenes, and other heavies). The selectivity results to products are presented in Table 3.

Table 3-Selectivity to thiophene products in mole base

\begin{tabular}{ccc} 
Selectivity & H-BEA & Mg-BEA \\
$\mathrm{H}_{2} \mathrm{~S}$ & 85.7 & 78.6 \\
Hydrothiophene & 0.3 & 0.6 \\
Cracking & 3.2 & 3.4 \\
Alkylation & 10.2 & 16.0 \\
Condensation & 0.6 & 1.4 \\
\hline
\end{tabular}


The main product observed in the catalytic conversion of thiophene was $\mathrm{H}_{2} \mathrm{~S}$. However, the incorporation of magnesium into the Beta zeolite resulted in lower selectivity to the formation of $\mathrm{H}_{2} \mathrm{~S}$, and increased selectivity to the formation of alkylated products, having, as the main one, methyl thiophene. Jaimes et al. (2009), while studying thiophene reactions on zeolites, proposed that the alkylation of thiophene reaction can occur between a thiophene molecule and different hydrocarbon molecules adsorbed on neighboring sites, which, according to Shan et al. (2002), occur through the electrophilic attack in $\alpha$ and $\beta$ positions in the thiophene molecule. The increase in Bronsted site density in the incorporation of calcium and magnesium ions by cationic exchange in zeolites, according to Miotto and Machado (2002), is due to the generation of acidic sites $\mathrm{CaOH}^{+}$and $\mathrm{MgOH}^{+}$based on the dissociation and adsorption of water molecules at high temperature, promoted by the existing electrostatic field around the cations:

$\mathrm{X}^{2+}+\mathrm{H}_{2} \mathrm{O} \Rightarrow \mathrm{X}\left(\mathrm{OH}_{2}\right)^{2+} \Rightarrow \mathrm{XOH}^{+}+\mathrm{H}^{+}$

Several paths are proposed for the formation of reaction products observed in Table 3 . However, the mechanism of successive hydrogenations of the thiophenic ring, converting it to hydroderivatives through hydrogen transfer - which, on itself, are cracked into hydrogen sulfide - presents itself as the most elucidative to the products obtained in this study (POTAPENKO et al., 2014). From the results of selectivity to HT in n-hexane cracking (Table 2) and selectivity to the formation of $\mathrm{H}_{2} \mathrm{~S}$ in thiophene conversion (Table 3), we observed that the catalyst with the highest selectivity to hydrogen transfer (H-BEA), presented a higher rate of formation of $\mathrm{H}_{2} \mathrm{~S}$. The incorporation of magnesium to the Beta zeolite inhibited selectivity to hydrogen transfer and presented a lower selectivity to the formation of $\mathrm{H}_{2} \mathrm{~S}$. Such results are in accordance with those found by Potapenko, Doronin and Sorokina (2012), who, while studying selectivity to $\mathrm{H}_{2} \mathrm{~S}$ in 2-methyl thiophene cracking in a load of undecane, observed that an increase in selectivity to hydrogen transfer reactions, in several catalysts, presented a higher selectivity to the formation of $\mathrm{H}_{2} \mathrm{~S}$.

\section{CONCLUSIONS}

Both catalysts, H-BEA and Mg-BEA, demonstrated to be active for hydrocarbon cracking reactions and desulfurization of compounds present in the gasoline fraction. The addition of magnesium to the catalyst increased the cracking of $n$-hexane and favored the formation of alkylated sulfurized compounds. The incorporation of magnesium into the Beta zeolite increased the number of Bronsted acidic sites, which promote the cracking of hydrocarbons, and improved catalyst adsorptive capacity through modifications in Lewis sites' nature on the surface. Hydrogen transfer, result of hexane cracking, favored thiophene conversion and $\mathrm{H}_{2} \mathrm{~S}$ formation.
CORMA, A., GONZALEZ-ALFARO, V., ORCHILLES, A. V. Catalytic cracking of alkanes on MCM-22 zeolite. Comparison with ZSM-5 and beta zeolite and its possibility as an FCC cracking additive. Applied Catalysis A: General, v. 129, n. 2, p. 203-215, 1995.

CORMA, A., MARTÍNEZ, C., KETLEY, G., BLAIR, G. On the mechanism of sulfur removal during catalytic cracking. Applied Catalysis A: General, v. 208, p. 135-152, 2001

CORMA, A, SAUVANAUD, L. FCC testing at bench scale: New units, new processes, new feeds. Catal Today, v. 218, p. 107-114, 2013.

DEL RIO, D, BASTOS, R, SEDRAN, U. Commercial additives for sulfur control in FCC gasoline: Overall analysis of their impact on LCO and gasoline. Catal Today, v. 213, p. 206-210, 2013.

DEHGHAN, R., ANBIA, M. Zeolites for adsorptive desulfurization from fuels: A review. Fuel Processing Technology, v. 167, p. 99-116, 2017.

GUPTA, A. K., IBRAHIM, S., SHOAIBI, A. AL. Advances in sulfur chemistry for treatment of acid gases. Progress in Energy and Combustion Science, v.54, p. 65-92, 2016.

JAIMES, L., FERREIRA, M. L., DE LASA, H. Thiophene conversion under mild conditions over a ZSM-5 catalyst. Chemical Engineering Science, v.64, n.11, p.2539-2561, 2009.

KARAKHANOV, E. A., GLOTOV, A. P., NIKIFOROVA, A. G., VUTOLKINA, A. V., IVANOV, A. O., KARDASHEV, S. V., MAKSIMOV, A. L., LYSENKO, S. V. Catalytic cracking additives based on mesoporous MCM-41 for sulfur removal. Fuel Processing Technology, v.153, p. 50-57, 2016.

LEE, K. X., VALLA, J. A. Investigation of metal-exchanged mesoporous Y zeolites for the adsorptive desulfurization of liquid fuels. Applied Catalysis B: Environmental, V. 201, p. 359-369, 2017.

LEFLAIVE, P., LEMBERTON, J. L., PÉROT, MIRGAIN, C., CARRIAT, J. Y., COLIN, J. M. On the origin of sulfur impurities in fluid catalytic cracking gasoline Reactivity of thiophene derivatives and of their possible precursors under FCC conditions. Applied Catalysis A: General, v.227, p. 201-215, 2002.

LERSCH, P.; BANDERMANN, F. Conversion of chloromethane over metal-exchanged ZSM-5 to higher hydrocarbons. Applied Catalysis, v. 75, n. 1, p. 133-152, 1991.

MIOTTO, D. M. M., MACHADO, N. R. C. F. Utilização de zeólitas modificadas $\mathrm{CaX}$ e $\mathrm{MgX}$ como adsorventes de compostos orgânicos. Acta Scientiarum. Technology, v. 24, p. 1627-1635, 2002.

NODA, T.; SUZUKI, K.; KATADA, N.; NIWA, M.. Combined study of IRMS-TPD measurement and DFT calculation on Brønsted acidity and catalytic cracking activity of cation-exchanged Y zeolites.Journal of Catalysis, v.259, p. 203-210, 2008.

PENZIEN, J., ABRAHAM, A., BOKHOVEN, J. A., JENTYS, A., MÜLLER, T. E., SIEVERS, C., LERCHER, J. A. Generation and Characterization of Well-Defined $\mathrm{Zn} 2+$ Lewis Acid Sites in Ion- 
Exchanged Zeolite BEA. The Journal of Physical

Chemistry B, v.108, p.4116-4126, 2004.

POTAPENKO, O. V., DORONIN, V. P., \& SOROKINA, T.

$\mathrm{P}$. Influence of $[\mathrm{H}]$-donating activity of hydrocarbons on transformations of thiophene compounds under catalytic cracking conditions. Petroleum Chemistry, v. 52, n. 1, p. 55-59, 2012.

POTAPENKO, O.V., DORONIN, V.P., SOROKINA, T.P., KROL, O.V., LIKHOLOBOV, V.A.Hydrogen transfer in transformations of olefin and thiophene compounds for the refining of gasoline fractions. Fuel Processing Technology, v.128, p. 251-256, 2014.

SHAN, H. H., LI, C. Y., YANG, C. H., ZHAO, H., ZHAO, B. Y., ZHANG, J. F. Mechanistic studies on thiophene species cracking over USY zeolite. Catalysis Today, v. 77, p. 117-126, 2002.

ZAFARI, R., KHARAT, A. N., Application of Zeolitic Additives in the Fluid Catalytic Cracking (FCC). Journal of nanostructure, v.3, n.2, p. 209-217, 2013. 